\section{A DESTRUCTIVE PLANT PARASTTE.}

$A$ DISEASE of vine-leaves, characterised by the presence of brown or blackish blotches, which frequently spread over the entire surface of the leaf, has been known in European and American vine-growing districts under various provincial names for some years. This disease, known in France as brunissure, was investigated by Viala and Sauvageau, who concluded that it was due to the presence of a parasitic organism to which the name Plasmodiophora vitis was given. Prof. Debray's researches show that brunissure is far more generally distributed than was hitherto suspected, having been detected by this observer in plants belonging to forty-two natural orders. In like manner, the leaf is not the part most frequently attacked, as supposed by Viala, but root, branch, flower, and in fact every portion of a plant is liable to attack. Owing to the absence of spore-formation, zoospores, nuclei, and slender pseudopodia, coupled with the fact that, although a parasite, there is no trace of malforma tion of the host, Debray considers that the organism under consideration cannot be included in the Plasmodiophoræ, nor in any other recognised family, and proposes for its reception a new family, Pseudocommidex, and a new genus, Psendocommis, allied to Vampyrellae and Myxomycetæ. The supposed or ganism when in plant cells is difficult to distinguish from the protoplasm of the cell, and more especially the nucleus; it is, however, more refringent, and usually remains intact after the protoplasm has been destroyed by the use of eau de Javelle. Iodine-green and methylene-blue give a green and blue stain respectively; the most certain reaction, however, is said to be chlor-iodide of zinc, which gives a yellow or brown colouration to the plasmodia. The organism is met with under various forms in the cells of the host, never occurring in the intercellular spaces; the plasmodium may be intimately mixed with, and almost indistinguishable from the protoplasm of the cell, or dis tinct from the cell-contents and densely vacuolate, or finally, in assuming a spherical form, perfectly homogeneous, or with a few spherical vacuoles. Under certain conditions the plasmodium travels from the interior of the cells of the leaf or other part of the plant to the surface, where it appears as a slimy or gummy secretion, and by this means passes on to other parts of the plant which are attacked. Sometimes the external plasmodium becomes hardened into wax-like masses or cysts, which are considered to represent a resting-stage. The appearance and spread of the disease is much influenced by meteorological conditions, a sudden chill favouring its development. No preventive based on experiment is given, but it is suggested that badly diseased parts should be removed, and the external migration of the parasite checked by a dusting of powdered lime.

If Debray's 'observations prove to be correct, we have in Pseudocommis the most universally diffused and destructive of plant parasites hitherto known.

\section{SCIENCE IN THE MAGAZINES.}

F VERY individual, as Prof. Milnes Marshall used to say, climbs up his own genealogical tree. Embryology shows how human lineaments are developed from a widely typical animal form, and evidences of the same relationship can be obtained from the study of the infant after birth. In the Fortnightly, Prof. Sully pleads for such study. "Ours is a scien. tific age," remarks he, "and science has cast its inquisitive eye on the infant. We want to know what happens in the first all-decisive two or three years of human life, by what steps exactly the wee amorphous thing takes shape and bulk, both physically and mentally. And we can now speak of the beginning of a careful and methodical investigation of child nature by men trained in scientific observation. This line of inquiry, started by physicians, as the German Sigismund, in connection with their special professional aims, has been carried on by a number of fathers and others having access to the infant, among whom it may be enough to name Darwin and Preyer." The biologist is able to use the physical development of a child to show man's kinship to the lower animal world, and the development of an infant's mind indicates to the psychologist how the mental history of the race has been evolved. It does not need a very acute observer to see the intellectual and moral resemblances between the lowest existing races of mankind and

1 "La Brunissure chez les végétaux," Rèu'te de Viticulture, 5 Rue GayLussac.

NO. I 358 , VOL. 53$]$ children. Several anthropologists have studied this phase of child-life, and have found it full of interest. The difficulty is to get systematic and scientific observations of children. Prof. Sully shows that the work is worth doing, and indicates some of the lines of study to be followed; all that is needed is methodical and trustworthy registration of the successive stages in the child's development.

A second article in the Fortnightly is a reply by Prof. Karl Pearson to an article in the September number of the Review, where Dr. St. George Mivart attempted to describe the limits of scientific knowledge and inquiry, and to show that many teachers of science were dogmatic, or "denominational," as he called it. Two other articles in which some of our readers may find interest are "Brahminism and the Foundations of Belief," by Vamadeo Shastri, and "Vegetarianism," by Mr. T. P. Smith.

An article on Pasteur, contributed by Profs. Patrick Geddes and $\mathrm{J}$. A. Thomson to the Contemporary, is a readable and fairly full statement of his personal life and scientific work. The authors thus sum up Pasteur's legacy to the world : "There is the impulse which he gave, after the successful organisation of his own Institute, to the establishment in other countries of similar laboratories of preventive medicine, and, one may also say, of experimental evolution. There is his educative work at Strassburg and Lille, at the Ecole Normale and the Sorbonne, and, above all, in the smaller yet world-wide circle of his immediate disciples. To general biology his chief contribution has been the demonstration of the part which bacteria play, not only in pathological and physiological processes, but in the wider drama of evolution. To the chemist he has given a new theory of fermentation; to the physician, many a suggestive lesson in the etiology of diseases; and a series of bold experiments in preventive and curative inoculation, of which Roux's treatment of diphtheria, and Prof. Fraser's new remedy for snake-bites, are examples at present before the public; to the surgeon, a stable foundation, as Lister acknowledged, for antiseptic treatment ; to the hygienist, a multitude of practical suggestions concerning water-supply and drainage, disinfection and burial. On brewer, distiller, and wine-maker he has forced the microscope and its results; and he has shown both agriculturist and stockbreeder how some, at least, of their many more than ten plagues may be either averted or alleviated." In the same Review Mr. Herbert Spencer traces the development of the judge and lawyer, and points out the relations between the priestly and judicial functions. There is also a forcible and philosophical reply by Father Tyrrell to Miss Cobbe's utterances in the October number. We content ourselves with giving two of the thirteen points upon which Father Tyrrell bases his position; they are: (I) as animals vary in sensibility, our duties concerning them vary also; (2) in the abstract, vivisection is not only permissible but laudable in certain conditions. Whether these conditions are or can be realised is a matter of opinion. He concludes: "Whatever one may think of the old-fashioned psychology on which this system rests, no one can deny that it is at least coherent and in keeping with the common sense of the best part of mankind, and that it offers a full and firm basis for a humane and reasonable treatment of animals, without entailing any of those hopeless problems which Miss Cobbe has to encounter in the application of her system."

A fine portrait of the late Prof. von Helmboltz, taken on the day of his last appearance in the lecture room, by C. Riborg Mann, appears in Scribner, accompanied by a brief summary of his leading contributions to science. The circumstances under which the photograph was taken are thus stated by the author: "At the close of his lecture on Saturday, July 7, 1894, Prof. von Helmholtz, at my earnest request, remained a few minutes in the class room and allowed me to photograph him. He stands as he was accustomed to appear before his students, the formulas as he had just written them remaining on the blackboard as a suitable background. By a strange working of fate, that was the last day on which he lectured, excepting one, when he gave some matter supplementary to this occasion; and this is his last photograph." A paper entitled "The Logic of Mental Telegraphy," contributed by Prof. Joseph Jastrow to the same magazine, should be taken to heart by a gullible public. Nothing is said about the attempted experimental tests of thought-transference, which may be worth investigation, but it is shown that coincidences will account for the possibilities of mental telegraphy believed in by the popular mind.

A few reminiscences of Huxley's habits and work at the 
Royal College of Science, South Kensington, are contributed by Prof. G. B. Howes to the October number of the College's Magazine, and are accompanied by an excellent portrait of Huxley; This article throws some interesting side-lights upon Huxley's great personality, especially with reference to his bearing towards his students and subordinates.

A passing allusion will suffice for the remaining articles of scientific interest in the magazines that have reached us. Longman's contains a popular description of the making of kelp, by Mr. D. J. Robertson, and also a paper on the disappearance of gulls from "Pallinsburn Gull Pond," by Mr. P. Anderson Graham. In Good Words Sir Robert Ball writes on "Halley," Sir Herbert Maxwell, Bart., pleads for the preservation of the "Fowls of the Air," and the Marquis of Ormonde describes a short cruise to Norway and Spitzbergen. The Sunday Magazine contains the concluding paper by "Eha," on "Voices of the Indian Night." Chambers's Journal has, among the subjects of its popular articles: "The Coal of the World," "Migrations of Fish," "Some Modern Uses of Glass," and "A Bundle of Paradoxes." The Strand Magazine has a number of graphical representations of statistics referring to the coinage productions of the Royal Mint, by Mr. J. Holt Schooling. The National contains a brief appreciative note on Pasteur's work. In addition to the magazines mentioned, we have received the Quarterly Review, Century Magazine, Humanitarian (in which occurs a paper by Prof. W. F. Barrett, on "Dynamic Thought"), and the English Illustrated Magazine.

\section{THE GEOLOGICAL SURVEY OF THE UNITED KINGDOM. ${ }^{1}$}

Summary of the chief Scientific Results obtained DURING THE YEAR I894.

\section{England and Wales.}

THE survey of the Lower Silurian rocks of the Isle of Man has been continued by Mr. G. W. Lamplugh, who finds that the Skiddaw slates of this island, although they possess much lithological variation, are essentially the same mass throughout and are hardly likely to disclose any base to the series. Nor has it been possible to trace any sub-divisions, equivalent to those in the Lower Silurian rocks elsewhere, owing to the absence of fossils.

Reference was made in the previous Report (1893) to certain conglomerates or breccias which it was suggested may have been produced by the breaking up of sandy slates and grits under intense shear strain. These remarkable rocks have been found during the past year to attain an importance altogether unsuspected. Mr. Lamplugh has traced them in definite bands following the prevailing strike of the Skiddaw slates, and generally intercalated between an argillaceous and a more or less arenaceous group of strata. He has found one band to run continuously for eight miles, and thereafter, somewhat less clearly, for four miles further.

In the area of South Wales considerable tracts of Old Red Sandstone have been mapped during the past year by Mr. J. R. Dakyns and Mr. A. Strahan ; and so far the following local subdivisions have been recognised :-

(3) Grey quartz-grits and conglomerates with some red sandstones. This group forms the uppermost of the whole series.

(2) Massive red sandstones with some conglomerates and a few red shales, as well as occasional grey sandstones and thin limestones (cornstones).

(I) Red and variegated marls with bands of soft red sandstone and thin limestones (cornstones).

These three sub-divisions pass into each other.

In Devonshire and Cornwall the re-survey of the Devonian formation and associated igneous rocks has been continued by Mr. Ussher, who has recognised that Upper Devonian strata are largely developed in the southern parts of these counties. Thus they are found skirting the Dartmoor granite, from Kingsbridge Road to Shaugh Prior, not far from Plymouth. In the Plymouth district, they consist of slates with local volcanic materials and a mass of porphyritic diabase at Ford, near Devonport. As they range into Cornwall, they present some specially interesting

1 Extracted from "Annual Report of the Geological Survey by Sir Archibald Geikie, D.Sc., LL.D., F.R.S., Director General," published in the Report of the Science and Art Department for the year 1894 .

No. I 358 , vOL. 53$]$ features. Besides retaining their evidence of contemporaneous volcanic action, they have yielded fossils which prove their stratigraphical position and allow of their being correlated with the Upper Devonian group of other regions.

The progress of mining, since first the maps of the coal-fields were published, has been so great that many of these maps have become more or less obsolete. It is therefore highly desirable, from an industrial and national point of view, that the surveys of our mineral fields should be revised, in order to place within reach of the mining community, and of the public generally, an accurate representation of the various coal-fields on which so much of the material prosperity of the country depends.

The re-survey of the great coal-field of South Wales has now been in progress for three years, and during the past year that of the North Staffordshire and Leicestershire fields has been begun.

During last summer certain improvements were made in the mapping of the Whitehaven district, particularly in regard to the boundaries between the formations and the positions of the faults. One of the most interesting points in this re-examination, made by Mr. A. Strahan, was the proof obtained of the existence of two distinct systems of faults, the one older than the Permian period and running from south-west to north-east, the other later than that period and trending from south-east to north-west. This fact had been previously insisted upon by Mr. J. D. Kendall, to whom the Survey is greatly indebted for his generous courtesy in supplying all the information which he had amassed during a residence of many years in the district as a mining engineer.

The chief work of the past year among the Cretaceous forma. tions has been the tracing, by Mr. Jukes-Browne, of the various sub-divisions of the Chalk over tracts of the southern counties where they had not been previously mapped. Apart from its scientific interest this re-survey of the Chalk is of great economic importance. The maps will henceforth show at a glance the distribution of the various members of the Chalk, and thus will furnish accurate information for the guidance of those who have to sink wells or deal with the water-supply and drainage of the wide chalk-districts of the south of England.

Mr. Whitaker and Mr. Reid have continued the revision of the Tertiary strata in the Hampshire Basin.

During the past year the survey of the Superficial Deposits for the construction of an agronomic map of the country has made good progress in the midland and southern counties, and much new information has been obtained with regard to the extent of the drifts in Monmouthshire and South Wales.

In the valleys that intersect the South Wales coal-field, and chiefly end in the broad dip-slopes of the northern outcrop of Millstone Grit, much boulder-clay as well as gravel has been noticed by Mr. Gibson. It is almost entirely of local origin. That these uplands were overspread with ice is shown by the occurrence of glacial strix on the Millstone Grit at a height of about I 500 feet above the sea. Further proof that the ice must have existed in considerable mass has been obtained in the excavations of some new waterworks at Nant-y-bwch, where a hill of sandstone upwards of 200 yards in length has been found to be a transported mass. Though its bedding is only slightly disturbed, yet the whole mass has been ascertained to lic upon boulder-clay, and must therefore be regarded as a huge boulder.

In the Isle of Man, Mr. Lamplugh has observed that the marked distinction referred to in the previous Report, between the insular drift of the hills and the extra-insular drift of the low ground still continues. The relative distribution of these drifts seems to prove that both are of truly glacial origin. Most of the deeper glens in the Isle of Man were probably filled with local glaciers before the coming of the great south-flowing icesheet which afterwards overrode the island up to its highest summits. As shown by numerous striæ observed on the Skiddaw slates, the general march of the ice during the height of the glaciation seems to have been from some point west of north, instead of east of north, as usually stated. A bed of fine warp or silt in the glacial series of Kirk Michael may prove to be of some economic value. It has been locally used in past time as a fuller's earth, and an effort is now about to be made to introduce it to a wider market for the same purpose.

\section{Scotland.}

As announced in the previous Report, all the tracts of Lewisian gneiss on the mainland, from Cape Wrath to the Kyles of Skye, have been mapped, but there are many displaced tracts or slices of that formation which lie to the east of the great line of com- 